\title{
PENERAPAN PENDEKATAN SCIENTIFIC DALAM PEMBELAJARAN BAHASA INDONESIA BERBASIS TEKS DI KELAS VIII SMP MUHAMMADIYAH 4 MALANG
}

\author{
Tuti Kusniarti'1), Gigit Mujianto ${ }^{2)}$, Sudjalil ${ }^{3)}$ \\ FKIP Universitas Muhammadiyah Malang \\ Emai1 ${ }^{1)}$ : toetyhidayat@gmail.com \\ Email2) $^{2}$ gigitm67@gmail.com \\ Email $^{3)}$ : sudjalil_24@yahoo.co.id
}

\begin{abstract}
ABSTRAK
Kurikulum 2013 menempatkan bahasa Indonesia sebagai penghela ilmu pengetahuan (Nuh, 2013:37). Penguatan bahasa Indonesia sebagai penghela Ilmu pengetahuan menunjukkan betapa pentingnya bahasa Indonesia dalam kedudukan dan perannya sebagai bahasa nasional termasuk pembelajaran bahasa Indonesia di sekolah. Penerapan Kurikulum 2013 pada pembelajaran bahasa Indonesia di sekolah, lebih menekankan pembelajaran yang berbasis teks, proses berpikir yang sistematis dan terkontrol melalui kegiatan pengumpulan data, analisis, dan penyajian hasil analisis. Hal ini sangatlah penting dan dapat meningkatkan hasil belajar siswa serta memunculkan proses kegiatan belajar mengajar yang lebih efektif. Tujuan penelitian ini antara lain; 1) mendeskripsikan model pembelajaran berbasis teks; 2) mendeskripsikan proses penilaian yang dilakukan oleh guru, dan 3) mendeskripsikan tindak lanjut kegiatan PPDS.
\end{abstract}

Kata kunci: Pembelajaran Bahasa Indonesia, pendekatan saintifik, berbasis teks

\begin{abstract}
Curriculum 2013 put Bahasa Indonesia as the support of knowledge (Nuh, 2013:37). Developing Bahasa Indonesia as the support of knowledge is showing the importance of Bahasa Indonesia in its position and function as national language to be included in the learning at school. The implementation of curriculum 2013 in learning Bahasa Indonesia at school emphasizes on text-based learning, sistematic and controlled thinking process through data collection activity, analysis, and presentation of the result of analysis. The learning is very important and able to increase the student's result of learning and showing effective teaching and learning process. The purposes of the research are: 1) to describe the text-based learning model, 2) to describe the scoring process conducted by the teacher, ad 3) to describe the follow-up of PPDS.
\end{abstract}

Keywords: Learning Bahasa Indonesia, scientific approach, text-based.

\section{PENDAHULUAN}

Pembelajaran Bahasa Indonesia di sekolah yang menerapkan Kurikulum 2013, menuntut adanya suatu model pembelajaran yang melibatkan siswa. Hal ini maksudkan agar proses belajar mengajar tidak monoton menjadi milik guru semata.
Kondisi di sekolah menunjukkan masih banyak guru meyampaikan materi pembelajaran hanya sekedar menyampaikan materi tanpa melibatkan siswa untuk mencapai hasil yang maksinal.

Sehubungan dengan itu Program penugasan dosen di sekolah (PPDS) yang merupakan kegiatan resmi Fakultas 
Keguruan dan Ilmu Pendidikan merupakan salah satu program yang bertujuan untuk melihat efektivitas pembelajaran dan menjelang diberlakukannya PPG untuk guru yang belum tersertifikasi. Program ini telah diinisiasikan melalui Program Hibah MBS pada tahun 2010-2011. Hakikat dari Program PPDS adalah melibatkan dosen secara langsung mengajar di sekolah sebagai guru model dan dan menjalankan tugas lainnya yang menunjang program program di sekolah.

Penugasan dosen di sekolah tidak hanya dalam bidang pengajaran saja namun ada bidang lain yang dapat diterapkan di sekolah, diantaranya memberikan binaan pada sekolah mitra yang berhubungan dengan pengajaran dan pengajaran. PPDS di bidang pengajaran dan bermanfaat mengalirkan IPTEKS pembelajaran yang dikembangkan di LPTK kepada sekolah tempat PPDS berlangsung dan sebagai upaya menambah wawasan persekolahan pada dosen yang bertugas di sekolah.

Sehubungan dengan itu, banyak permasalahan yang ditemui oleh guru dalam mengaplikasikan Kurikulum 2013 menuju pembelajaran Metode pembelajaran yang dianjurkan dalam Kurikulum 2013 adalah pendekatan ilmiah atau scientific, akan tetapi pada kenyataannya di lapangan masih ditemukan guru yang memiliki kemampuan untuk menciptakan dan menggunakan metode pembelajaran berbasis scientific walaupun penerapan Kurikulum 2013 telah berlangsung selama satu tahun terutama pada sekolah sasaran.

Berdasarkan observasi awal di sekolah, beberapa guru mempunyai persepsi bahwa mengajar dengan menerapkan pendekatan ilmiah merupakan sebuah kegiatan yang sulit dan membutuhkan biaya besar. Hal inilah yang menyebabkan mutu pelajaran kurang maksimal, seyogyanya dalam meningkatkan profesionalisme guru maka yang bersangkutan dituntut untuk dapat mengembangkan proses pembelajaran yang lebih bermakna dengan melibatkan siswa. Pemanfaatan metode pembelajaran yang inovatif dan didukung oleh semua pihak serta adanya pembinaan dari LPTK menungkinkan akan terjadi peningkatan profesionalisme guru dan meningkatkan kualitas pembelajaran di era serba teknologi ini.

Hasil pemantauan sementara menunjukkan bahwa di Sekolah Menengah Pertama (SMP) Muhammadiyah 4 Malang belum sepenuhnya pembelajaran dilaksanakan menggunakan pendekatan ilmiah terutama kelas VIII untuk mata pelajaran Bahasa Indonesia, seyogyanya pelaksanaan Kurikulum 2013 telah diterapkan saat siswa duduk di kelas VII, namun belum semua guru menerapkan pendekatan ini dalam proses pembelajaran.

Prinsip-prinsip dalam pembelajaran yang menggunakan pendekatan ilmiah salah satunya disebutkan bahwa siswa akan berhasil dalam belajar apabila mendapatkan rangsangan belajar, baik visual, auditif, praktik, maupun audiovisual. Selain itu ada simulasi belajar yang mengkondisikan situasi belajar menjadi satu kesatuan antara metode, strategi, bahan ajar, dan kondisi belajar. Untuk mengatasi kesenjangan ini perlu adanya pelatihan pengembangan media dan bahan ajar kepada guru untuk meningkatkan mutu proses dan hasil pembelajaran dan profesionalisme guru sebagai tenaga pendidik.

Penugasan dosen di sekolah merupakan kebijakan yang memberikan keuntungan pada kedua belah pihak baik bagi LPTK maupun bagi sekolah mitra. 
Program PDS membutuhkan komitmen dosen untuk mengalami dan menjadi guru model di sekolah mitra. Menjadi guru bagi seorang dosen di sekolah adalah hal baru, dan ini perlu adanya penyesuaian dengan berbagai hal yang berlaku di sekolah.

Penugasan dosen di sekolah bagi sekolah mitra memungkinkan adanya berbagai masalah, antara lain apakah dosen yang bertugas dapat menyesuaikan diri dengan lingkungan tempat sekolah mitra, karena ini sangat berbeda dengan perguruan tinggi tempat mengajar dosen.

Sehubungan dengan diberlakukannya Kurikulum 2013 di semua sekolah, maka dituntut perlu adanya profesionalisme guru dalam mengembangkan pembelajaran di kelas. Salah satu tuntutan guru dari profesinya adalah mampu menyelenggarakan pembelajaran yang mendidik dengan menerapkan pendekatan ilmiah (Scientific) dalam proses belajar mengajar di dalam kelas. Pembelajaran yang mendidik adalah pembelajaran yang membangkitkan inspirasi peserta didik, pembelajaran yang dapat diciptakan melalui penggunaan metode pembelajaran yang tepat dan mengikuti amanah Kurikulum 2013.

\section{Pendekatan Ilmiah dalam Pembelajaran Bahasa Indonesia Berbasis Teks}

Penempatan bahasa Indonesia sebagai penghela ilmu pengetahuan memberikan penegasan akan pentingnya kedudukan bahasa Indonesia sebagai bahasa nasional yang mempersatukan berbagai etnik yang berbeda latar belakang, bahasa lokal dan kedudukannya sebagai bahasa resmi negara.

Selain sebagai bahasa resmi negara, bahasa Indonesia juga ditujukan sebagai bahasa ilmu pengetahuan yang dipakai dalam dunia pendidikan, sebagai bahasa pengantar proses pembelajaran dan juga diharapkan sebagai pengantar penyebaran informasi ilmu pengetahuan, artinya semua sumber informasi yang ada di Indonesia wajib menggunakan bahasa Indonesia sebagai bahasa pengantarnya.

Satuan bahasa yang mengandung makna, pikiran, dan gagasan adalah teks. Teks tidak selalu berwujud bahasa tulis, sebagaimana lazim dipahami, misalnya teks Pancasila yang sering dibacakan pada saat upacara. Teks dapat berwujud, baik teks tulis maupun teks lisan (bahkan dalam multi modal: perpaduan teks lisan dan tulis serta gambar/ animasi/film). Teks itu sendiri memiliki dua unsur utama. Pertama, adalah konteks situasi penggunaan bahasa yang di dalamnya ada register yang melatarbelakngi lahirnya teks, yaitu adanya sesuatu (pesan, pikiran, gagasan, ide) yang hendak disampaikan (field) (Sunarto. 2010).

Sasaran atau kepada siapa pesan, pikiran, gagasan, atau ide itu disampaikan (tenor), dalam format bahasa yang bagaimana pesan, pikiran, gagasan, atau ide itu dikemas (mode). Terkait dengan format bahasa, teks dapat berupa deskripsi, prosedural, naratif, cerita petualangan, anekdot, dan lain-lain. Unsur kedua adalah konteks situasi, yang di dalamnya ada konteks sosial dan konteks budaya masyarakat tutur bahasa yang menjadi tempat teks tersebut diproduksi.

Pembelajaran bahasa Indonesia di sekolah yang menerapkan Kurikulum 2013 menuntut adanya suatu proses pembelajaran berbasis teks dengan menggunakan pendekatan ilmiah (saintifik). Proses belajar mengajar di kelas menerapkan proses pembelajaran yang menggunakan pola berpikir sistematis, terkontrol, empirik, dan kritis dalam 
menerapkan prosedur ilmiah yang berupa pengumpulan data, analisis data, dan penyajian hasil analisis.

Sebagai contoh, data yang diperlukan untuk menyusun teks deskripsi berbeda dengan data yang diperlukan untuk menyusun teks cerita. Pada teks deskripsi, data yang diperlukan antara lain informasi atau fakta yang merupakan bagian unsur yang menjadi penanda keberadaan sesuatu yang bersifat khusus, pada teks cerita diperlukan data atau fakta suatu peristiwa yang dialami oleh seseorang yang digambarkan dari persfektif waktu, tempat, akibat atau komplikasi serta solusi atau cara mengatasi akibat yang ditimbulkan dari peristiwa tersebut. Perbedaan wujud data tersebut tidak lain disebabkan oleh perbedaan fungsi atau tujuan sosial dari setiap teks.

Terkait perbedaan antara satu jenis teks tertentu dan jenis teks lain. Perbedaan dapat terjadi, misalnya pada struktur teks itu sendiri. Sebagai contoh, teks deskripsi dengan teks prosedural berbeda strukturnya meskipun kedua teks tersebut termasuk ke dalam kategori jenis teks faktual. Apabila teks deskripsi memiliki ciri tidak terstruktur dan tidak bersifat generalisasi, teks prosedural justru bersifat terstruktur dan dapat digeneralisasi.

Struktur Bahasa Indonesia Ekspresi Diri dan Akademik teksnya juga berbeda. Jika pada teks deskripsi strukturnya terdiri atas pernyataan umum yang diikuti pernyataan deskriptifnya, struktur teks prosedural terdiri atas tujuan langkahlangkah. Begitu pula kedua jenis teks tersebut berbeda dengan teks cerita/naratif. Di samping jenisnya berbeda dengan kedua jenis teks di atas, yaitu masuk ke dalam kategori teks jenis sastra, juga strukturnya berbeda, teks yang terakhir ini terdiri atas judul, orientasi (kapan, siapa, dan di mana), komplikasi (masalah apa yang terjadi dan mengapa terjadi), serangkaian peristiwa, resolusi/klimaks, dan koda (bagaimana cerita berakhir).

Struktur teks membentuk struktur berpikir sehingga dalam setiap penguasaan jenis teks tertentu, siswa akan memiliki kemampuan berpikir sesuai dengan struktur teks yang dikuasainya. Dengan berbagai macam teks yang sudah dikuasainya, siswa akan mampu menguasai berbagai struktur berpikir. Bahkan, satu topik tertentu dapat disajikan dalam jenis teks yang berbeda dan tentunya dengan struktur berpikir yang berbeda pula.

Dengan memperhatikan jenis-jenis teks itu, serta adanya unsur utama yang harus dimiliki sebuah teks salah satunya adalah mode (sarana bahasa yang digunakan untuk mengemas pesan, pikiran, gagasan, ide yang disampaikan melalui teks) melalui pembelajaran bahasa berbasis teks, materi sastra dan kebahasaan dapat disajikan.

Selain memperhatikan teks, guru sebagai motor utama penggerak pembelajaran di kelas, seyogyanya harus memperhatikan jenis teks atau genre naskah atau teks yang akan digunakan. Menurut Martin (dalam Pangesti, 2013) genre merupakan serangkaian langkah yang ditempuh untuk mencapai suatu tujuan sosial yang terwujud dalam bentuk teks lisan, tulis, multimodal (perpaduan teks tulis, lisan, gambar). Dalam teks terdapat struktur teks dan tekstur (kohesi, appraisal, hubungan konjungtif, leksiko-gramatika, dan grafologi (tulis) atau fonologi (lisan).

Hal-hal lain yang juga perlu diperhatikan dalam membahas teks antara lain; a) Generic structure (bagaimana teks diorganisasikan); b) Piranti kohesi (bagaimana gagasan dikaitkan); c) Kosakata (kata-kata apa 
yang digunakan dan mengapa); d) Tatabahasa (bagaimana kata-kata disusun); e) Intonasi, paragraf, dan tanda baca (bagaimana ide penting disampaikan); f) Ejaan (bagaimana huruf dirangkaikan), dan g) Ciri non-kebahasaan (hal lain yang mempengaruhi makna).

Berkaitan dengan genre teks, menurut Depdikbud (2013) ada hal lain yang juga harus menjadi perhatian guru dalam menentukan teks. Bahasa merupakan media yang penting dalam teks. Pemilihan bahasa dalam teks diwarnai oleh oleh halhal berikut,.

a. Apa yang dibahas (field)?

b. Siapa yang berinteraksi (tenor)? c. Bagaimana kabar disampaikan (mode).

d. Field, tenor, dan mode ini tercakup dalam konteks sosial masyarakat pemakai bahasa. Pemakaian bahasa dalam suatu masyarakat sosial didasarkan pada suatu tujuan sosial tertentu.

e. Aspek kebahasaan (struktur bahasa dan fungsinya) dibahas secara kontekstual karena jenis teks tertentu mempunyai karakter kebahasaan tertentu pula, sesuai konteksnya.

f. Misalnya, teks prosedur menggunakan sederetan kalimat perintah yang tidak dijumpai pada jenis teks lain.

\section{Genre Teks menurut Brian PALTRIDGE 2004}

\section{Teks Cerita}

\begin{tabular}{|c|l|l|}
\hline \multirow{4}{*}{$\begin{array}{c}\text { Teks } \\
\text { Cerita }\end{array}$} & \multicolumn{1}{|c|}{ Genre } & \multicolumn{1}{c|}{ Tujuan } \\
\cline { 2 - 3 } & Kisahan & Menceritrakan \\
\cline { 2 - 3 } & Narasi & $\begin{array}{l}\text { Menyelesaikan komplikasi dalam } \\
\text { sebuah cerita. }\end{array}$ \\
\cline { 2 - 3 } & $\begin{array}{l}\text { Exemplum } \\
\text { (bahasa Itali) }\end{array}$ & $\begin{array}{l}\text { Menilai karakter atau perilaku dalam } \\
\text { cerita. }\end{array}$ \\
\cline { 2 - 3 } & Anekdot & $\begin{array}{l}\text { Berbagi reaksi emosional dalam sebuah } \\
\text { cerita. }\end{array}$ \\
\hline
\end{tabular}

\section{Teks Tanggapan}

\begin{tabular}{|l|l|l|}
\hline \multirow{4}{*}{$\begin{array}{l}\text { Teks } \\
\text { Tanggapan }\end{array}$} & \multicolumn{1}{|c|}{ Genre } & \multicolumn{1}{c|}{ Tujuan } \\
\cline { 2 - 3 } & $\begin{array}{l}\text { Tanggapan } \\
\text { Pribadi }\end{array}$ & Bereaksi emosional terhadap teks. \\
\cline { 2 - 3 } & Mereviu & $\begin{array}{l}\text { Mengevaluasi teks, sastra visual, atau } \\
\text { musik. }\end{array}$ \\
\cline { 2 - 3 } & Panafsiran & $\begin{array}{l}\text { Menafsir/memaknai pesan sebuah } \\
\text { teks. }\end{array}$ \\
\cline { 2 - 3 } & Tanggapan Kritis & Menanggapi pesan teks. \\
\hline
\end{tabular}

Tuti Kusniarti dkk., Penerapan Pendekatan Scientific dalam Pembelajaran Bahasa Indonesia 
3. Teks Argumentasi

\begin{tabular}{|l|l|l|}
\hline \multirow{2}{*}{$\begin{array}{l}\text { Teks } \\
\text { Argumentasi }\end{array}$} & Genre & Tujuan \\
\cline { 2 - 3 } & Eksposisi & $\begin{array}{l}\text { Mendebat suatu sudut pandang } \\
\text { lingkungan dan sosial. }\end{array}$ \\
\cline { 2 - 3 } & Diskusi & $\begin{array}{l}\text { Mendikusikan dua atau lebih sudut } \\
\text { pandang. }\end{array}$ \\
\hline
\end{tabular}

4. Teks Cerita Faktual

\begin{tabular}{|l|l|l|}
\hline \multirow{3}{*}{ Teks Cerita } & Genre & Tujuan \\
\cline { 2 - 3 } & $\begin{array}{l}\text { Menceritrakan } \\
\text { Otobiografi }\end{array}$ & $\begin{array}{l}\text { Menceritrakan peristiwa dalam } \\
\text { kehidupan. }\end{array}$ \\
\cline { 2 - 3 } & $\begin{array}{l}\text { Menceritrakan } \\
\text { Otobiografi }\end{array}$ & Menceritrakan tahap kehidupan. \\
\cline { 2 - 3 } & Menceritrakan Sejarah & Menceritrakan peristiwa sejarah. \\
\cline { 2 - 3 } & Ihwal Sejarah & Menceritrakan peristiwa sejarah. \\
\hline
\end{tabular}

5. Teks Penjelasan

\begin{tabular}{|l|l|l}
\hline \multirow{3}{*}{ Penjelasan } & Genre & Tujuan \\
\cline { 2 - 3 } & Penjelasan yang Berurut. & Menjelaskan suatu urutan. \\
\cline { 2 - 3 } & Penjelasan. & Menjelaskan beberapa penyebab. \\
\cline { 2 - 3 } & Penjelasan Sebab-Akibat & Menjelaskan efek ganda. \\
\hline
\end{tabular}

6. Teks Laporan Hasil Observasi

\begin{tabular}{|l|ll|l|}
\hline Laporan & Genre & Tujuan \\
\cline { 2 - 4 } & $\begin{array}{l}\text { Laporan } \\
\text { Klasifikasi }\end{array}$ & dengan & $\begin{array}{l}\text { Mengelompokkan jenis dan } \\
\text { menggambarkan fenomena. }\end{array}$ \\
\cline { 2 - 4 } & $\begin{array}{l}\text { Laporan } \\
\text { Unsur }\end{array}$ & Berdasarkan & $\begin{array}{l}\text { Menggambarkan bagian dari } \\
\text { keutuhan. }\end{array}$ \\
\hline
\end{tabular}

7. Teks Prosedur

\begin{tabular}{|l|l|l|}
\hline Prosedur & Genre & Tujuan \\
\cline { 2 - 3 } & Prosedur & $\begin{array}{l}\text { Bagaimana melakukan percobaan dan } \\
\text { pengamatan. }\end{array}$ \\
\cline { 2 - 3 } & Penceritaan Prosedur & Percobaan dan pengamatan. \\
\hline
\end{tabular}

Genre Teks menurut Droga, Louis dan Humphrey, Sally (2005)

1. Teks Deskripsi Faktual

Tujuan sosial: menggambarkan ciri

khas tertentu, tempat, orang, atau benda. Teks-teks ini tidak selalu berupa jenis teks "berbeda dan sering terselip di dalam jenis teks yang lebih panjang.
2. Teks Laporan Informasi

Tujuan sosial: laporan informatif digunakan untuk memberikan informasi umum tentang berbagai kelas benda, seperti ular, kota, komputer, batu, dan lain-lain.

3. Teks Prosedur

Tujuan sosial: teks menunjukkan 
beberapa tahap sesuai dengan langkah-langkah yang telah ditentukan. Ada perintah, arah, petunjuk, panduan, aturan, dan resep.

4. Teks Melaporkan Prosedur

Tujuan sosial: untuk merekam langkah-langkah yang ditempuh dalam melaksanakan investigasi. Khususnya sangat penting untuk merekam pengalaman belajar praktis dalam sains dan teknologi seperti eksperimen dan pengumpulan data.

5. Teks Melaporkan Fakta

Tujuan Sosial: faktual menceriterakan tentang apa yang terjadi dengan mendokumentasikan serangkaian peristiwa dan mengevaluasi signifikansinya. Teks dapat menceriterakan sejarah, otobiografi, atau biografi. Selain itu juga dapat digunakan untuk merekam peristiwa dan pengamatan dalam kunjungan lapangan dan wisata.

6. Teks Penjelasan

Tujuan Sosial: untuk menjelaskan secara ilmiah bagaimana fenomena teknologi dan alam terwujud, bagaimana cara atau hal-hal terjadi. Penjelasan sekuensial menekan kan pada urutan atau tahap-tahap suatu proses-bagaimana sutau proses terjadi (misalnya siklus hidup kupu-kupu). Penjelasan kausal memberi perhatian penyebab peristiwa-peristiwamengapa proses terjadi (misalnya mengapa gelombang pasang terjadi).

7. Teks Eksposisi

Tujuan Sosial: eksposisi (penjelasan terperinci/ perawian) adalah jenis teks persuasif yang berdebat suatu kasus atau terhadap suatu sudut pandang tertentu. Beberapa eksposisi membujuk pembaca untuk berpikir dengan cara tertentu dengan menerima teori atau posisi. Jenis lainnya membujuk pembaca untuk bertindak dengan cara tertentu.

8. Teks Diskusi

Tujuan sosial: Diskusi digunakan untuk melihat suatu masalah dari berbagai perspektif, sebelum membuat keputusan atau rekomendasi.

9. Teks Sastrawi

a. Deskripsi sastra menggambarkan ciri karakteristik dari orang tertentu.

b. Tempat atau objek (sering imajinatif). Jenis ini tidak selalu merupakan jenis teks yang berbeda dan sering menjadi bagian dalam teks-teks sastra seperti narasi.

10. Teks Naratif

Tujuan sosial: naratif sering digunakan untuk menyampaikan pesan tentang bagaimana seseorang mengungkapkan kehidupan yang pernah dialami dalam suatu kejadian. Narasi sering menyampaikan pesan tentang bagaimana orang-orang diharapkan untuk berprilaku ketika dihadapkan pada jenis budaya tertentu kita.

11. Teks Pelaporan Sastrawi

Tujuan Sosial: untuk menceriterakan kembali serangkaian kegiatan dengan tujuan menghibur. Pelaporan sastrawi melibatkan pengalaman pribadi atau imajinasi.

12. Teks Tanggapan

Tujuan Sosial: merupakan jenis teks yang digunakan untuk meringkas, menganalisis, dan mennaggapi sastra, teks karya seni atau pertunjukkan. Teks ini dapat berupa respon pribadi atau reviu. 


\section{PEMBAHASAN}

Penelitian ini menggunakan pendekatan kualitatif dengan metode deskriptif. Data berupa peristiwa yang terjadi saat proses belajar mengajar, dokumen dari guru, dan pengamatan.

Penugasan Dosen di Sekolah merupakan program yang sudah ditetapkan oleh FKIP Universitas Muhammadiyah Malang dalam rangka menyambut diberlakukannya Pendidikan Guru dalam Jabatan. Kegiatan ini bukan saja bermanfaat untuk dosen namun juga sangat dibutuhkan oleh sekolah mitra sebagai upaya pengembangan profesionalisme guru dalam hal memperluas wawasan dan sebagai bentuk implementasi kompetensi yang harus dimiliki oleh seorang pendidik.

Kegiatan yang telah dilaksanakan selama kurang lebih delapan bulan dalam jadwal yang sudah ditentukan, memang tidak sepenuhnya terlaksana dalam waktu yang tertulis. Kegiatan ini baru terlaksana sesuai dengan kalender akademik pihak sekolah dan kesepakatan bersama yang telah ditentukan oleh pihak sekolah mitra.

Sebelum pelaksanaan penugasan dosen di sekolah, tim dari Jurusan Pendidikan Bahasa dan Sastra Indonesia melakukan observasi awal dengan menemui pimpinan sekolah dan guru yang akan dijadikan sasaran pelatihan serta menentukan kelas yang akan dipakai sebagai tempat kegiatan.

Berdasarkan hasil observasi awal, kebutuhan yang diperlukan oleh guru adalah semacam pelatihan tentang programprogram yang berkaitan dengan pengembangan wawasan sebagai seorang guru yang dituntut untuk profesional dalam hal membuat perencanaan pembelajaran terutama yang berbasis Kurikulum 2013.
Kegiatan awal yang dilakukan di sini adalah guru dan dosen bersama-sama mencermati RPP yang sudah dibuat oleh guru berdasarkan pengalaman yang sudah dimilikinya. Temuan awal memang masih adanya kesulitan guru dalam hal menentukan kompetensi yang harus dicapai oleh siswa. Setelah beberapa kali bertemu dan melakukan perbaikan untuk rancangan pembelajarannya serta memberikan bantuan dalam hal penyediaan media serta beberapa referensi, guru telah menguasai pembuatan rencana pembelajaran yang berbasis Kurikulum 2013.

Pembelajaran di kelas juga sangat menyenangkan, walau di awal beberapa siswa merasa malu untuk mengungkapkan ide-idenya ketika guru atau dosen bertanya. Kegiatan di kelas yang menyenangkan membuat siswa merasa nyaman sehingga tidak malu-malu lagi untuk mencoba aktif di dalam kelas. Hal ini terlihat pada dokumentasi berikut.

Kegiatan di dalam kelas ketika guru dan dosen memberikan pembelajaran di depan kelas pada siswa kelas VIII SMP Muhammadiyah 4 Malang. Diskusi di kelas menghadirkan tema "Teks Prosedural:, kegiatan ini meminta siswa untuk mengamati dulu pemutaran video, hasil pengamatan dilaporkan dalam bentuk laporan berupa teks katagori prosedural.

Salah seorang dosen memberikan penjelasan pada siswa urutan-urutan kegiatan yang harus dilakukan berkaitan dengan materi yang sudah dijelaskan oleh guru sebelumnya.

Kegiatan kolaborasi yang dilakukan oleh guru bersama tim di dalam kelas tidak menjadikan siswa takut untuk berkomunikasi, awalnya beberapa siswa agak malu-malu ketika ada pertanyaan 
atau diminta menanggapi oleh guru namun suasana menjadi lebih cair setelah guru memberikan penguatan-penguatan pada jawaban yang diberikan oleh siswa.

\section{Kontribusi Program pada Sekolah Mitra}

Program penugasan dosen di sekolah mempunyai dampak yang positif bagi sekolah mitra. Kegiatan ini baru kali pertama dilaksanakan sekolah mitra yang didampingi langsung oleh tim dari FKIP Universitas Muhammadiyah Malang. Dampak yang dirasakan langsung oleh guru adalah pembinaan dalam pengembangan perangkat pembelajaran yang sesuai dengan kebutuhan sekolah masingmasing dengan tetap memperhatikan kurikulum yang digunakan oleh pihak sekolah.

Pembelajaran di dalam kelas menjadi lebih hidup karena guru selalu melibatkan siswa dalam aktivitas pembelajaran di kelas. Siswa dikenalkan dengan kegiatan pembelajaran yang menggunakan pendekatan saintific melalui langkahlangkah yang menyenangkan siswa.

Program ini sebaiknya tetap terus dikembangkan di sekolah-sekolah mitra, karena pembinaan seperti ini jarang sekali didapat oleh guru yang mengajar di sekolah swasta. Pihak sekolah mitra menginginkan adanya peningkatan pada program-program lainnya, seperti penulisan karya ilmiah ataupun penelitian tindakan kelas yang lebih berbobot dengan bimbingan dari pihak kampus.

\section{Kendala yang Dihadapi dan Upaya yang Dilakukan}

Kendala yang dihadapi saat melaksanakan kegiatan penugasan dosen di sekolah adalah sulitnya menentukan pertemuan melalui pembinaan oleh tim dan sekolah mitra. Kegiatan ini di satu sisi menguntungkan guru yang mendapatkan bimbingan namun tidak dengan guru yang tidak terlibat dalam kegiatan ini. Beberapa hal yang mungkin dapat disimpulkan adalah:

1. Kurangnya waktu pertemuan yang disediakan oleh pihak sekolah, dikarenakan sudah terikat dengan kalender akademik sekolah.

2. Pendampingan hanya dapat dilakukan di saat guru mitra mempunyai waktu luang saja. Pada situasi ini guru mitra hanya memiliki waktu satu hari kosong di SMP Muhammadiyah 4 Malang, karena yang bersangkutan juga mengajar ditempat lain sebagai konsekuensi guru yang sudah tersertifikasi untuk mengajar tidak kurang dari 24 jam/minggu.

3. Pertemuan di kelas VIII hanya dapat dilakukan seminggu 2 kali pertemuan.

Upaya yang dilakukan untuk dapat memperkecil kendala tersebut adalah memaksimalkan pertemuan dengan guru mitra disela-sela guru mitra memiliki waktu luang setelah mengajar. Selain itu beberapa solusi yang ditawarkan adalah:

a. Data sering untuk menyepakati ruang lingkup PDS;

b. Menentukan KI dan KD bersama guru mintra yang akan dipraktekkan oleh dosen di dalam kelas untuk kegiatan yang akan datang;

c. Dosen dan guru mitra bersama-sama membuat RPP untuk pembelajaran;

d. Dosen melaksanakan pembelajaran dengan RPP yang telah dibuat bersama guru mitra;

e. Setelah pembelajaran, dosen memberikan pelatihan singkat pengembangan perangkat pembelajaran berbasis scientific kepada guru di sekolah bersama Tim pelaksana PDS; 
f. Refleksi hasil pelaksanaan pembelajaran dan pelatihan;

g. Pendampingan dan tindak lanjut pengembangan pembelajaran berbasis scientific.

\section{SIMPULAN}

Berdasarkan hasil pengamatan dan pelaksanaan kegiatan di lapangan serta pembahasan, maka dapat disimpulkan sebagai berikut:

a) Proses penerapan pendekatan saintific pada pembelajaran Bahasa Indonesia di kelas VIII berjalan sesuai dengan rencana yang telah disusun oleh guru bersama dosen. Kegiatan dimulai dengan mengamati (Di sini guru meminta siswa untuk mengamati video tentang langkahlangkah mencangkok tanaman) sesuai dengan prinsip pembelajaran yang menggunakan pendekatan ini yaitu $5 \mathrm{M}$ (mengamati, menanyakan, mengumpulkan informasi/ eksperimen, mengasosiasikan/mengolah informasi, dan mengkomunikasikan). Dari kegiatan mengamati berlanjut pada menanyakan, mencari informasi, mengolah data-data yang ditemukan lalu mendiskusikan dengan kelompoknya dan diakhiri dengan menyampaikan hasil diskusi kelompoknya.

b) Melalui pembelajaran yang menerapkan pendekatan saintific, guru dapat menilai langsung pembelajaran yang diterapkannya di dalam kelas. Hal ini terlihat pada saat guru mengamati kegiatan siswa, siswa tidak lagi banyak berdiam diri namun sudah mulai mampu membuat pernyataan dari apa yang dipelajarinya.

Tindak lanjut yang diinginkan oleh guru mitra adalah membuat laporan tentang pelaksanaan kegiatan pembelajaran agar dapat dijadikan sebagai laporan karya ilmiah yang dapat dipertanggungjawabkan.

\section{DAFTAR PUSTAKA}

Aqib Zainal, Elbam R. 2007. Membangun Profesionalisme Guru dan Pengawas. Bandung: YaramaWidya.

Depdikbud Kementrian Pendidikan dan Kebudayaan. 2013. Implementasi Kurikulum 2013 SMP/MTS Bahasa Indonesia: Materi Pelatihan Guru.

Pangesti. 2013 Belajar dan Pembelajaran. Jakarta: Rineka Cipta.

Sally, dkk. 2005. Grammar and Meaning An Introduction for Primary Teachers. New South Wales Australia: Target Texts.

Sunarto. 2010. Penggunaan Tri Media Pembelajaran untuk Meningkatkan Aktivitas Belajar Pendidikan Kewarganegaraan Di Kelas IX A SMP Negeri 10 Bandar Lampung. 